DOI: $\underline{10.32702 / 2307-2105-2019.10 .54}$

УДК: 330.3:338.4:745

\author{
Г. А. Іващенко, \\ кандидат економічних наук, \\ дочент кафедри міжнародного бізнесу та економічного аналізу \\ Харківського національного економічного університету імені Семена Кузнеця, Україна \\ ORCID: 0000-0001-6581-0862
}

\title{
ЗАБЕЗПЕЧЕННЯ ПОДАТКОВОЇ БЕЗПЕКИ
}

\author{
G. Ivashchenko \\ PhD in Economics, Associate Professor of the Department of International Business and Economic \\ Analysis, Simon Kuznets Kharkiv National University of Economics, Ukraine
}

\section{SOFTWARE TAX SECURITY}

Наведено рівні податкової безпеки: національна податкова безпеку, регіональна податкова безпеку, податкова безпеку платників податків.

Виділено стратегії податкової безпеки, а саме: стратегія максимальної податкової безпеки; стратегія ухилення від оподаткування; стратегія «пом'якшення» податкових наслідків; стратегія податкової оптимізаиії.

Виділено взаємозв'язок податкової безпеки та податкової культури. Систематизовано загрози для податкової безпеки пов'язані з діяльністю держави та з діяльністю платників податків.

Виділено основні види податкових ризиків. Наведено основні складові податкової політики підприємства: дотримання податкової дисципліни, моніторинг та зниження податкових ризиків, співвідношення сплачуваних податків та доходів, складання податкового календаря, очінка можливостей застосування податкових пільг, пошук можливостей відстрочення податкових платежів законним шляхом на максимально тривалий термін. Запропоновано основні напрями збільшення видобутку нафти та газу для ПАТ «Укрнафта».

Досліджено складові податкової безпеки організащії: податкове планування, податкова оптимізація, податкове навантаження, податкові ризики. Проаналізовано методи податкової оптимізаиії для підприємств.

Податкове навантаження - ие процентне відномення суми сплачуваних організацією податків до суми виручки за даними звітності організації. Показник податкового навантаження нижче середнього показника по галузі є однією з причин проведення виїзної податкової перевірки

Податкове планування й оптимізація оподаткування є взаємодоповнюючими складовими частинами ефективного фінансового менеджменту в компанії. Для кращої керованості фінансовими потоками $i$ економії коштів $i$ відбувається розробка $i$ впровадження ефективного податкового планування, щчо і приведе до оптимізації.

Податкова оптимізація полягає в розробиі та впровадженні різних законних схем зниження податкових відрахувань. Методи оптимізаиії оподаткування - $\epsilon$ надзвичайно важливим інструментарієм. Як при використанні принщипів, так і при впровадженні в звичну систему податкових відрахувань конкретного методу мінімізації податкового навантаження необхідно звертати увагу на раціональність застосування відповідного інструменту. 
The levels of tax security are given: national tax security, regional tax security, tax security of taxpayers.

Tax security strategies are highlighted, namely: maximum tax security strategy; tax evasion strategy; a tax mitigation strategy; tax optimization strategy.

The relationship between tax security and the tax culture is highlighted. Tax security threats are systematically linked to government and taxpayer activity.

The main types of tax risks are highlighted. The main components of the enterprise tax policy are given: compliance with tax discipline, monitoring and reduction of tax risks, correlation of taxes paid and income, drawing up of a tax calendar, assessment of possibilities of applying tax benefits, seeking opportunities to defer tax payments for the longest time. The main directions of increase of oil and gas production for PJSC "Ukrnafta" are offered.

The components of tax security of the organization are investigated: tax planning, tax optimization, tax burden, tax risks. Methods of tax optimization for enterprises are analyzed.

One of the main tools for implementing the economic security system will be a tax strategy to determine the best option for the enterprise to fulfill its obligations as a taxpayer.

Tax burden is the percentage of the amount of taxes paid by an organization to the amount of revenue according to the organization's reports. The tax burden below the industry average is one of the reasons for the on-site tax audit.

Tax planning and tax optimization are complementary components of effective financial management within a company. For better cash flow management and cost savings, effective tax planning is being developed and implemented, which will lead to optimization.

Tax optimization is the development and implementation of various legitimate tax deduction schemes. Tax optimization methods are an extremely important tool. It is necessary to pay attention to the rationality of using the appropriate instrument both when applying the principles and when introducing into the usual system of tax deductions a specific method of minimizing the tax burden.

Keywords: tax risk; tax security; tax culture; tax burden; tax planning; tax optimization; tax strategy.

Ключові слова: податковий ризик; податкова безпека; податкова культура; податкове навантаження; податкове планування; податкова оптимізащія; податкова стратегія.

Постановка проблеми у загальному вигляді та іï зв'язок із важливими науковими чи практичними завданнями. Однією із найсуттєвіших загроз підприємству щодо забезпечення реалізації власних стратегічних економічних інтересів при певних зовнішніх умовах $\epsilon$ існуюча податкова система. Тому існує необхідність розробки та застосування різноманітних методик організації і ведення роботи із забезпечення податкової безпеки як складової економічної безпеки.

Одним із головних інструментів реалізації системи економічної безпеки буде виступати податкова стратегія щодо визначення оптимального варіанту виконання підприємством обов'язків як платника податків.

Реалізація податкової стратегії буде впливати і на стратегію управління грошовими потоками, оскільки додаткові штрафні санкції - це додаткові витрати і відтік грошових коштів. Система фінансових ризиків, що потребує мінімізації, буде включати й податковий ризик збільшення податкових платежів у випадку розширення бізнесу або змін у податковому законодавстві.

Аналіз останніх досліджень і публікацій, в яких започатковано розв'язання даної проблеми і на які спирається автор, виділення не вирішених раніше частин загальної проблеми, котрим присвячусться означена стаття.

Дослідження теоретико-методичних і практичних аспектів забезпечення податкової безпеки знайшли відображення в працях таких провідних вчених , як: Грунін С.О. [2], Іванов А., Шликов В. [6], Камлик М.I. [7], Іванюта Т.М., Заїчковський А.О. [7], Донець Л.І. [7], Берлач А.І. [7], Малюта Л.Я [2], Полянська А.С., Трощенкова Т.А. [3], Соснін О.С., Пригунов П.Я. [7]. Але не відпрацьовано єдиного підходу щодо оцінювання та аналізу стану податкової безпеки підприємств нафтової галузі.

Формулювання цілей статті (постановка завдання). підприємства.

Метою написання наукової статті $\epsilon$ розробка методичного забезпечення податкової безпеки

Завданнями даної статті є наступні: визначення місця податкової безпеки в системі економічної безпеки суб'єктів господарювання; виявлення загроз податкової безпеки; проведення аналізу проблем та перспектив розвитку нафтогазової галузі в умовах енергетичної кризи; ідентифікація податкових ризиків на ПАТ «УКРНАФТА» Полтавському тампонажному управлінні; проведення оцінки та аналізу податкової безпеки 
ПАТ «УКРНАФТА» Полтавського тампонажного управління; вибір напрямів збільшення видобутку нафти та газу для підвищення податкової безпеки на ПАТ «УКРНАФТА» Полтавському тампонажному управлінні; удосконалення інформаційно-аналітичної бази забезпечення податкової безпеки підприємства; розробка методичного забезпечення податкової оптимізації на ПАТ «УКРНАФТА» Полтавському тампонажному управлінні.

Виклад основного матеріалу дослідження 3 повним обгрунтуванням отриманих наукових результатів. Податки є основним джерелом фінансових ресурсів, централізуються державою для забезпечення суспільно необхідних і законодавчо встановлених потреб. Надання державою суспільних благ і послуг, пов'язаних зі створенням нових робочих місць та підтриманням загальної зайнятості, соціальним забезпеченням та соціальним захистом, освітою і охороною здоров'я, правоохоронною діяльністю, фінансується переважно за рахунок податкових надходжень.

3 податковою системою і податковою політикою пов'язані інтереси не тільки держави, а й усіх громадян, шарів і груп населення, підприємств і організацій. Податки і податкова політика в сучасних умовах $\epsilon$ одним 3 найважливіших об'єктів ринкових реформ. Податки впливають на стан економіки, бюджетної, фінансове забезпечення органів місцевого самоврядування, від них залежить здатність держави виконувати свої функції.

Отже, податкова безпека є важливим елементом системи забезпечення економічної безпеки держави.

3 огляду на багатогранність поняття податкової безпеки, складність взаємозв'язків і взаємозалежності різних іiі елементів, а також необхідність врахування економічних інтересів фізичних і юридичних осіб платників податків, регіонів і держави з метою забезпечення сталого економічного зростання, податкова безпеку включає в себе такі рівні: національна податкова безпеку; регіональна податкова безпеку; податкова безпеку платників податків [5].

Національна податкова безпека - стан економіки, який забезпечує гарантоване надходження податкових платежів до бюджету, що дозволяє забезпечити захист національних інтересів в умовах мінливого зовнішнього середовища [7].

Регіональна податкова безпека - це стан оподаткування в регіоні, визначається рівнем місцевого оподаткування [5].

Податкова безпеку платників податків - це фінансово-економічне становище платника податків, забезпечує мінімізацію податкових ризиків за умови дотримання податкової дисципліни [5].

Зараз можна виділити чотири основні типи податкових стратегій, які незалежно від факту формального проголошення реалізуються підприємствами та впливають на інструментарій, що застосовується в рамках забезпечення податкової безпеки підприємств:

стратегія максимальної податкової безпеки спрямована на абсолютне виконання вимог податкового законодавства на основі абсолютного визнання позиції податкових органів з усіх спірних питань;

стратегія ухилення від оподаткування виражається у свідомому порушенні податкового законодавства (спотворенні доходів і (чи) витрат, маніпулюванні нормами цивільного права при кваліфікації угод, несплаті податків і ін.);

стратегія «пом'якшення» податкових наслідків припускає відмову від свідомо неправомірних угод і мінімізацію сумнівних господарських операцій;

стратегія податкової оптимізації проявляється в зменшенні величини податкових зобов'язань (чи перенесенні їх виконання на пізніші терміни), а також скороченні податкових ризиків за допомогою цілеспрямованих правомірних дій платника податків [6].

Важливим аспектом забезпечення податкової безпеки є дотримання прав, обов'язків і відповідальності суб'єктів податкових відносин, істотно визначається рівнем податкової культури в державі.

Податкова культура - це частина загальнонаціональної культури країни, відображає рівень розвитку суспільства, виражений в діючих нормах системи оподаткування, глибині податкових знань населення, усвідомленні необхідності виконання податкових зобов'язань, виконання своїх обов'язків як платниками податків, так і державою [6]. Таким чином, податкова культура стосується всього суспільства і включає в себе свідоме ставлення до податкового процесу на всіх його учасників.

Податковий ризик - це економічна категорія, яка характеризує невизначеність кінцевого результату діяльності щодо забезпечення надходжень коштів до бюджетів усіх рівнів, державних цільових фондів, унаслідок можливого впливу (дії) на нього низки об'єктивних та/або суб'єктивних факторів, неефективного адміністрування податків і порушень податкового законодавства (рис. 1).

Причини нормативно-правового характеру призводять також до ризику порушення податкового законодавства. Ця група чинників спричиняє можливість втрат як у держави, так і у платників. Наприклад, неправильне тлумачення платником тих чи інших положень нормативно-правових актів може призвести до несвідомого порушення податкового законодавства, а отже - до втрат через сплату донарахованих у результаті перевірок обсягів податків, фінансових санкцій та адміністративних штрафів [5]. 


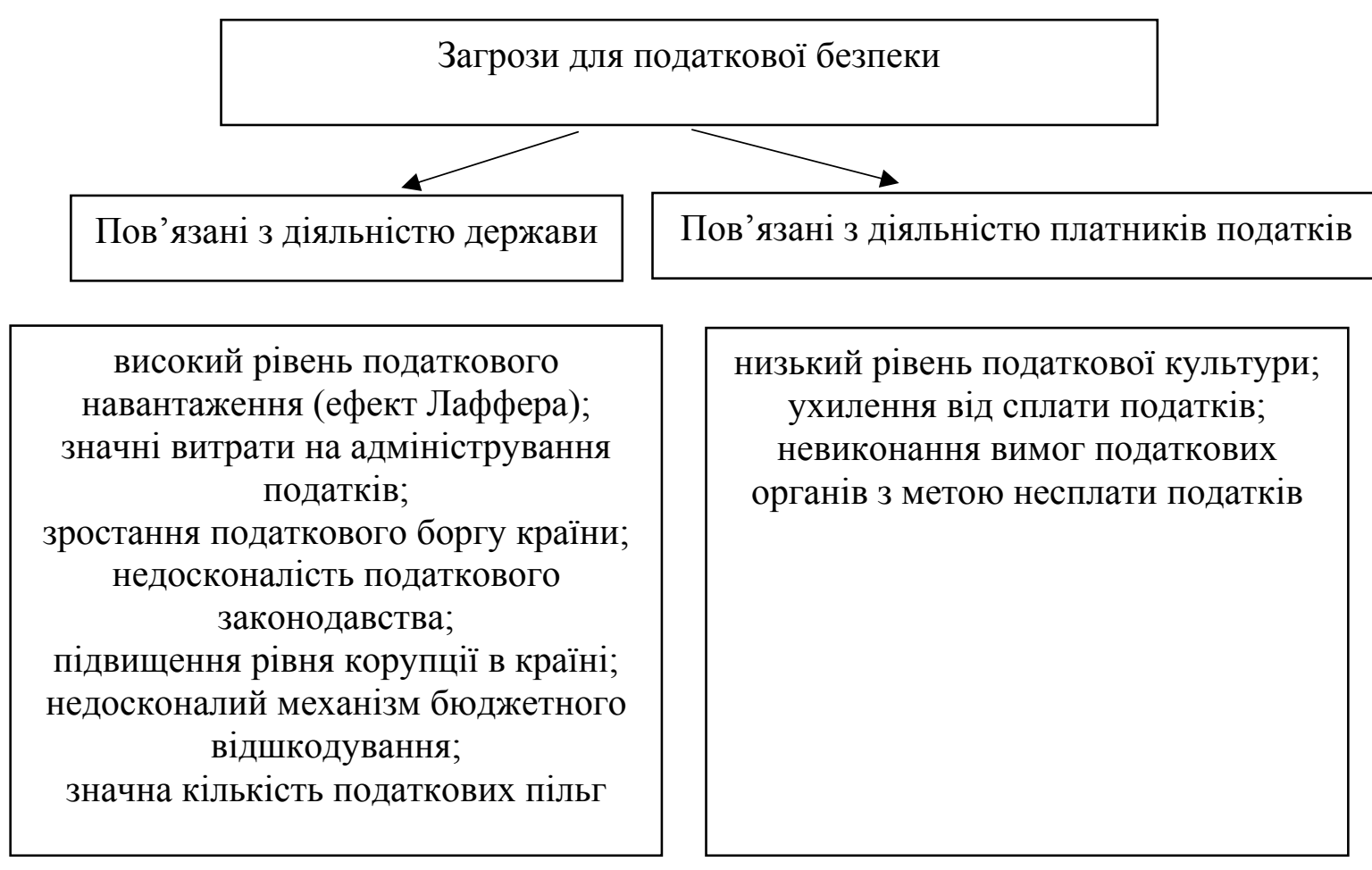

Рис. 1. Загрози для податкової безпеки

За 9 місяців 2018 року ПАТ «Укрнафта» сплатила 11,6 млрд грн податків

ПАТ «Укрнафта», що належить до п’ятірки найбільших платників податків України, за січень-вересень 2018 року сплатило податків на суму майже 11,6 млрд грн, включаючи 1,1 млрд грн у рахунок погашення простроченого податкового боргу. Податкові виплати компанії за цей рік вже перевищили аналогічний показник за весь 2017 рік на 13,7\% (10,2 млрд грн).

Водночас, незважаючи на відсутнє узгоджене урядом рішення щодо реструктуризації простроченого податкового боргу, в цьому році «Укрнафта» на регулярній основі виплачує податковий борг і вже повернула 1,1 млрд грн. Загалом консервативний план компанії передбачає повернення 1,2 млрд грн боргу в 2018 році (рис. 2).

\section{Ризик несплати податків}

Ризик податкового контролю

Ризик податкової мінімізації

\section{Ризик посилення податкового навантаження}

\section{Ризик карного переслідування податкового характеру}

Рис. 2. Основні види податкових ризиків ПАТ «УКРНАФТА» Полтавського тампонажного управління

На кінець третього кварталу 2018 року прострочений податковий борг ПАТ «Укрнафта» становив 10,7 млрд грн. Цей показник включає прострочену заборгованість самої компанії та ії структурних підрозділів, а також борг по спільній діяльності. Підхід «Укрнафти» до обліку податкового боргу відповідає чинному законодавству та узгоджується з рекомендаціями незалежного зовнішнього аудитора. Переважна його частина сформувалась впродовж 2014-2015 років до зміни менеджменту компанії.

«Укрнафта» сплатила 5,0 млрд грн ренти за 8 місяців. За серпень 2018 року ПАТ «Укрнафта» сплатило до державного та місцевих бюджетів різних рівнів 694,5 млн грн рентної плати за користування надрами за зобов'язаннями. Відповідно до закріпленого в законодавстві механізму розподілу рентної плати за видобуток нафти, газу та конденсату, з них 34,7 млн грн надійшло до місцевих бюджетів різних рівнів. 
В цілому, з початку цього року рентна плата компанії до бюджетів усіх рівнів склала 5,0 млрд грн, 3 яких 249,1 млн грн надійшло до місцевих скарбниць.

Найбільші відрахування з рентної плати, як і в попередні місяці, надійшли до громад Сумської, ІваноФранківської та Полтавської областей (табл. 1).

Таблиця 1.

5\% рентних платежів за видобуток нафти, газу та конденсату, які надійшли до бюджетів областей, районів та місцевих громад, млн грн

\begin{tabular}{|l|c|c|}
\hline \multicolumn{1}{|c|}{ Область } & За серпень, 2018 & 3а вісім місяців, 2018 \\
\hline Сумська обл. & 14,7 & 107,5 \\
\hline Івано-Франківська обл. & 7,9 & 55,4 \\
\hline Полтавська обл. & 5,2 & 37,4 \\
\hline Чернігівська обл. & 3,3 & 24,4 \\
\hline Львівська обл. & 2,9 & 19,8 \\
\hline Харківська обл. & 0,6 & 3,8 \\
\hline Дніпропетровська обл. & 0,07 & 0,6 \\
\hline Чернівецька обл. & 0,03 & 0,2 \\
\hline Всього & 34,7 & 249,1 \\
\hline
\end{tabular}

Принцип розподілу рентної плати за видобуток нафти та газу передбачає перерахування 95\% рентних платежів до загального фонду державного бюджету, а 5\% - до місцевих бюджетів. При цьому 2\% доходів від ренти спрямовуються в районні бюджети, а 3\% - до бюджетів міст обласного значення, бюджетів об'єднаних територіальних громад за місцем видобутку природних ресурсів. Таким чином, механізм розподілу ренти дає можливість громадам отримати частину доходів від видобутку нафти та газу.

На кінець третього кварталу 2018 року прострочений податковий борг ПАТ «Укрнафта» становив 10,7 млрд грн. Цей показник включає прострочену заборгованість самої компанії та ії структурних підрозділів, а також борг по спільній діяльності.

За останніми оцінками, в 2018 році ПАТ «Укрнафта» сплатить близько 6,4 млрд грн ренти, а, отже, до бюджетів областей, районів та громад надійде біля 320 млн грн доходів від рентних платежів.

Податкова політика підприємства, яка є механізмом захисту від податкових ризиків, включає такі складники:

вибір відповідної системи оподаткування з позицій мінімізації податкових платежів, визначення рівня податкового навантаження на підприємство;

співвідношення сплачуваних податків та доходів, складання податкового календаря, оцінка можливостей застосування податкових пільг; термін;

пошук можливостей відстрочення податкових платежів законним шляхом на максимально тривалий

дотримання податкової дисципліни;

контроль над правильністю і своєчасністю нарахування та сплатою податків у визначений термін;

достовірний облік, аналіз, контроль фінансової діяльності;

доступність податкових нормативно-правових актів;

моніторинг та зниження податкових ризиків [6].

Проблемою організації податкової безпеки підприємств є низький рівень податкової культури. Саме в складних умовах держава повинна підтримати значний рівень податкової безпеки країни, що, своєю чергою, допоможе суб'єктам господарювання проводити ефективну податкову політику з управління податковими ризиками.

В основі податкової безпеки організації лежить податкова оптимізація, податкове планування, оцінка податкових ризиків і навантаження шляхом використання спеціальних методів та інструментів оцінки їх впливу на економічну безпеку і ефективність діяльності організації [5].

Кожна організація в своїй діяльності прагне до отримання максимального прибутку при мінімальній податковому навантаженні, це призводить до різного роду правопорушень. Але не завжди організації йдуть на ризики з використанням незаконних схем ухилення від сплати податків, застосовуючи податкове планування. Використання законних методів зменшення податкової бази (податкового планування) здатне принести позитивний результат практично в будь-якому вигляді діяльності без загрози податкової безпеки підприємства, воно являє собою планування діяльності організації, спрямоване на мінімізацію ії податкових зобов'язань без порушень законодавства.

Складові податкової безпеки організації подано на рис. 3. 


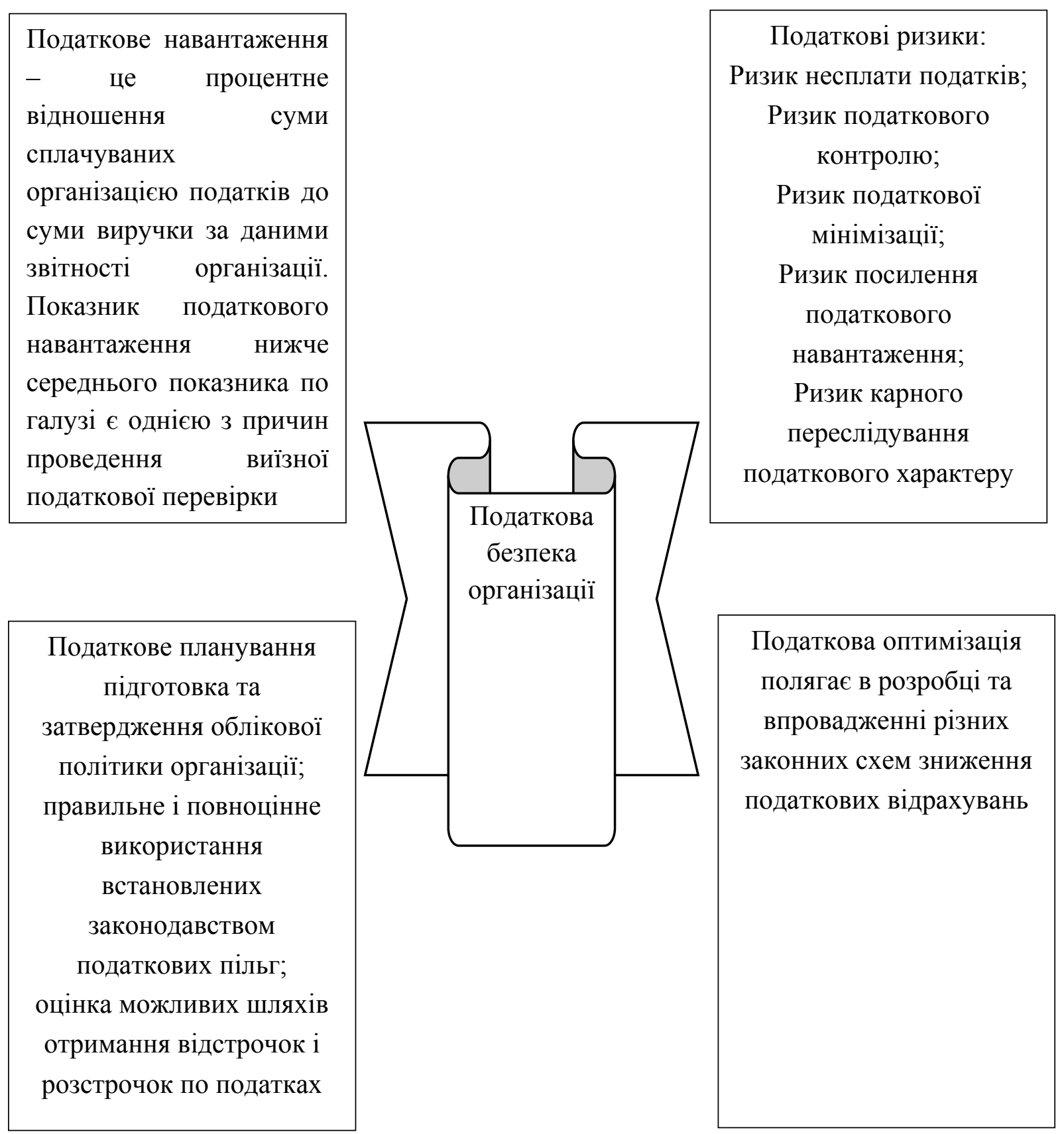

Рис. 3. Складові податкової безпеки організації 
Аналітична схема податкової безпеки ПАТ «Укрнафта» представлена на рис. 4.

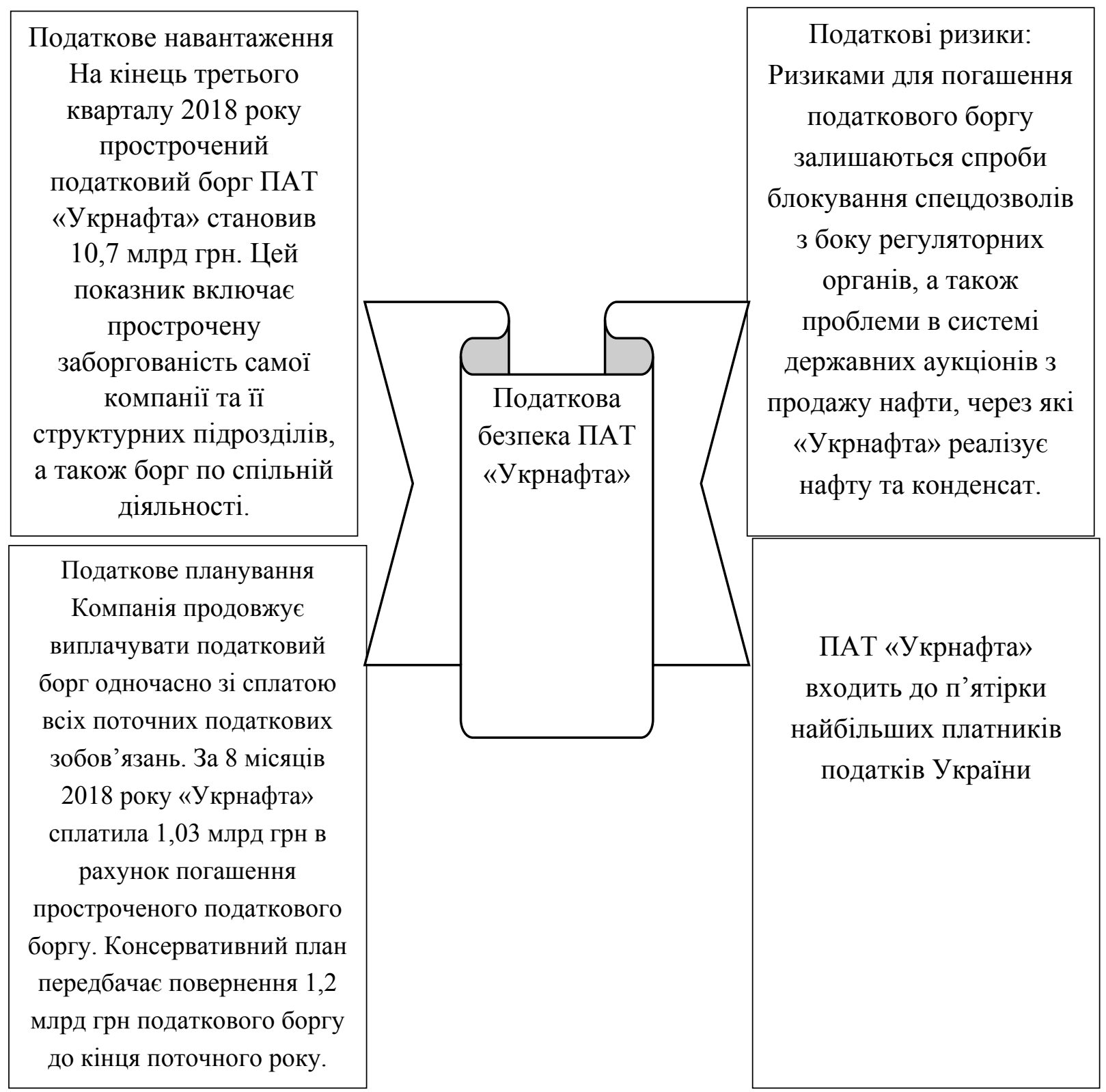

Рис. 4. Аналітична схема податкової безпеки ПАТ «Укрнафта»

Переважна кількість родовищ ПАТ «УКРНАФТА» слід віднести до важковидобувних із залишковими балансовими запасами газу 246,3 млрд м $^{3}$, обгрунтовано базові і надбазові об'єми видобування газу i конденсату.

Основні напрями збільшення видобутку нафти та газу для ПАТ «Укрнафта» Полтавському тампонажному управлінні надано на рис. 5. 


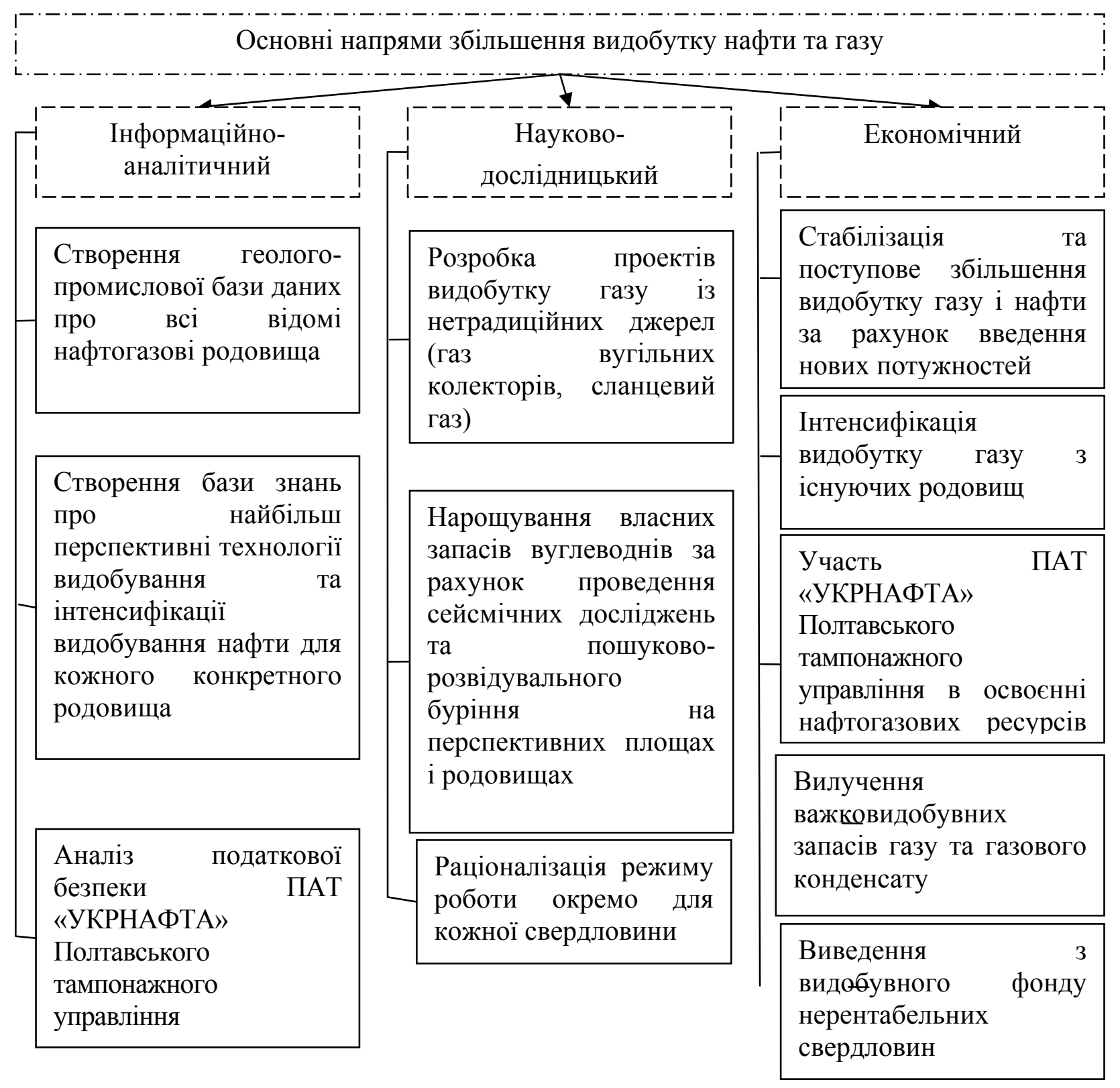

Рис. 5. Основні напрями збільшення видобутку нафти та газу для ПАТ «Укрнафта» Полтавському тампонажному управлінні

Методи оптимізації оподаткування - є надзвичайно важливим інструментарієм. Як при використанні принципів, так і при впровадженні в звичну систему податкових відрахувань конкретного методу мінімізації податкового навантаження необхідно звертати увагу на раціональність застосування відповідного інструменту, на основі чого і будується метод заміни (рис. 6). 

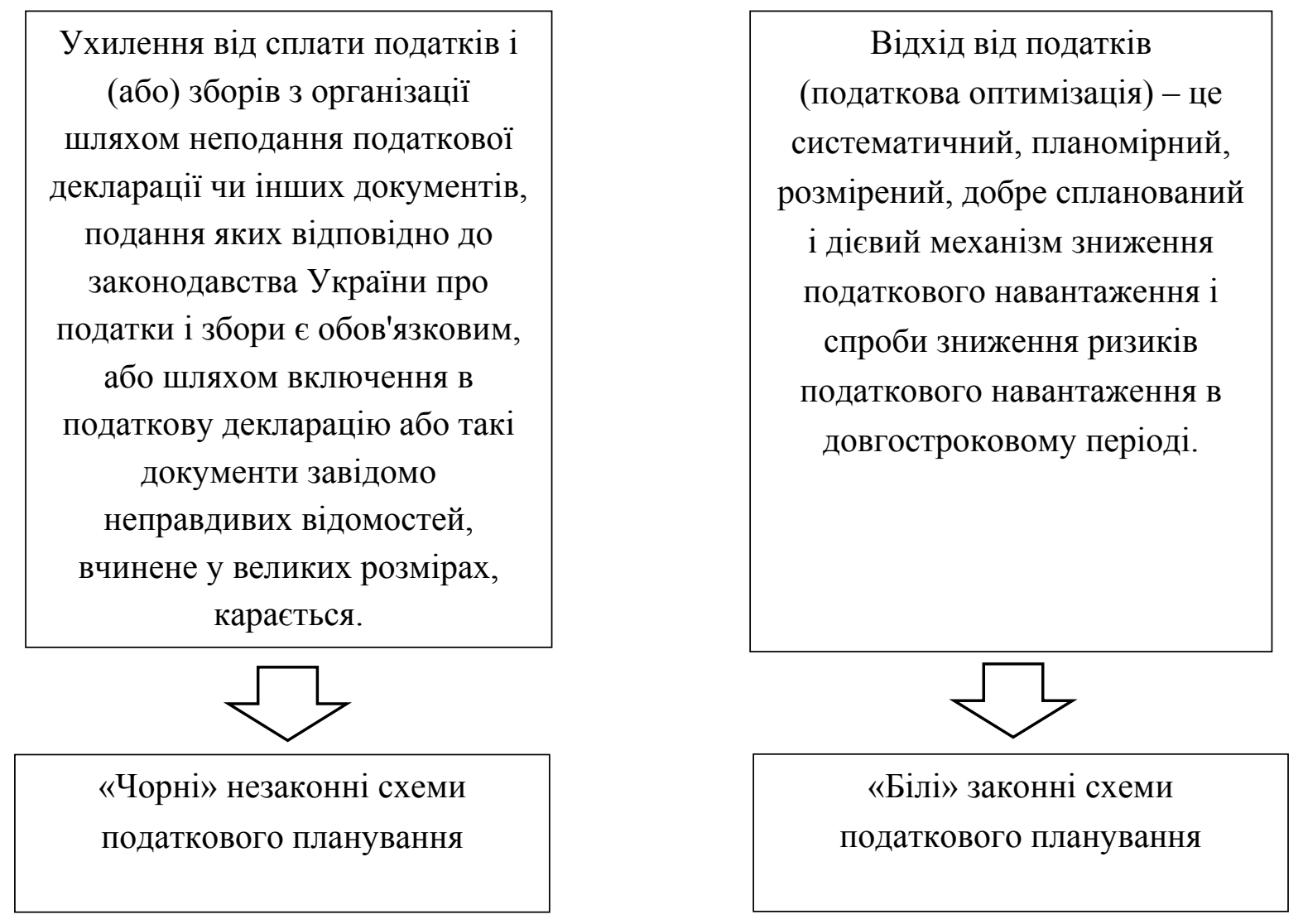

Рис. 6. Схеми податкового планування на підприсмстві

Податкове планування й оптимізація оподаткування є взаємодоповнюючими складовими частинами ефективного фінансового менеджменту в компанії. Для кращої керованості фінансовими потоками і економії коштів і відбувається розробка і впровадження ефективного податкового планування, що і приведе до оптимізації.

Податкова оптимізація - це спільна діяльність бухгалтера, юриста, керівника; постійний пошук нових оригінальних рішень і податкових схем організації; систематичне вивчення літератури описує нововведення, а також досвіду схожих по діяльності підприємств.

Методи податкової оптимізації для підприємств подано на рис. 7. 


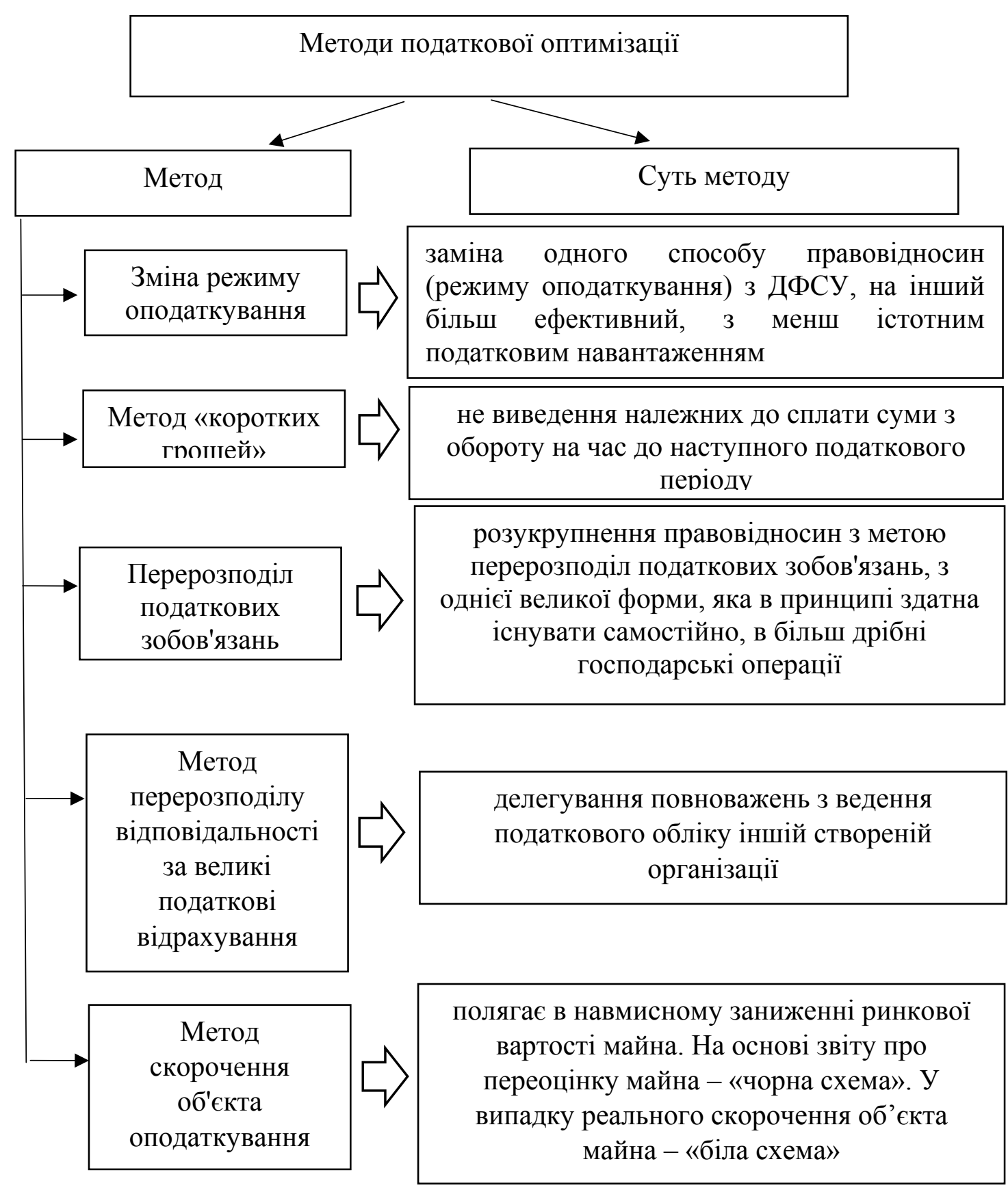

Рис. 7. Методи податкової оптимізації для підприсмств

Найбільш ефективні результати податкова оптимізація підприємства приносить при використанні всіх методів у комплексі, тобто використання всієї множини способів мінімізації податків.

Висновки 3 даного дослідження і перспективи подалыших розвідок у даному напрямі. Головним критерієм оцінки методів, є спрямованість дії. А саме спрямованість на подальше отримання економічної вигоди. Для керівників підприємств має бути правилом, що будувати методи оптимізації податкового навантаження не можна виключно на оціночному судженні зарубіжного досвіду планування та податкової оптимізації,

Найбільш ефективні результати податкова оптимізація підприємства приносить при використанні всіх методів у комплексі, тобто використання всієї множини способів мінімізації податків.

Схеми оптимізації податкових платежів стають останнім часом все більш особистісними, і всі вони підконтрольні основним принципами, які дозволяють і в кінцевому підсумку говорити про доцільність вибору методу та об'єднання всіх методів досягнення цілі.

Розглянуті схеми, методи, повинні підкорятися одному правилу, щоб вважатися «білим» і не змінювати свою «відтінку». Зниження податкових платежів шляхом виведення їх 3 податкового тягаря повинно супроводжуватися благом для компанії метою - це досягнення ділової цілі або з метою отримання прибутку в майбутньому періоді. 


\section{Література.}

1. Козаченко Г. В. Економічна безпека підприємства: сутність та механізм забезпечення: монографія // Г. В. Козаченко, В. П. Пономарьов, О. М. Ляшенко. - К.: Лібра, 2003. -280 с.

2. Отенко І. П. Аналіз та оцінка стратегічного потенціалу підприємства / І. П. Отенко, Л. М. Малярець, Г. А. Іващенко. Наукове видання. - Харків: Вид. ХНЕУ, 2007. - 348 с.

3. Отенко І. П. Економічна безпека підприємства: навчальний посібник / І. П. Отенко, Г. А. Іващенко, Д. К. Воронков. Харків: Вид. ХНЕУ, 2012. - 252 с.

4. Отенко І. П. Фінансовий аналіз. Навчальний посібник / І. П. Отенко, Г. Ф. Азаренков, Г. А. Іващенко. - Харків: Вид. ХНЕУ ім. С. Кузнеця, 2015. - 169 с.

5. Оцінка майна та майнових прав. Заг. ред. Скринько С. - К.: ТОВ «УКЦ «Експерт-Л» -2007 р. -746 с.

6. Петров М. І. Економічна безпека підприємства: сутність, трактування, точки зору / М. І. Петров // Менеджер. - 2002. - №1(17). - С. 67-71.

7. Петряєва 3. Ф. Верифікація градації рівнів фінансово-економічної безпеки підприємств / З. Ф. Петряєва, Г. А. Іващенко, О. О. Петряєв // Науковий економічний журнал «Актуальні проблеми економіки». № 5(179). - 2016. - C. $402-411$.

\section{References.}

1. Kozachenko, H.V. Ponomarov, V. P. and Lyashenko O. M. (2003) Ekonomichna bezpeka pidpryyemstva: sutnist ta mekhanizm zabezpechennya [Economic security of an enterprise: the essence and mechanism of provision], Libra, Kyiv, Ukraine.

2. Otenko, I. P. Malyarets, L. M. and Ivashchenko, G. A. (2007) Analiz ta otsinka stratehichnoho potentsialu pidpryyemstva [Analysis and evaluation of the strategic potential of the enterprise], Vyd. KHNEU, Kharkiv, Ukraine.

3. Otenko, I. P. and Ivashchenko, G. A. (2012) Ekonomichna bezpeka pidpryyemstva [Economic security of the enterprise], Vyd. KHNEU, Kharkiv, Ukraine.

4. Otenko, I. P. Azarenkov, H. F. and Ivashchenko, G. A. (2015) Finansovyy analiz [Financial analysis], Vyd. KHNEU, Kharkiv, Ukraine.

5. Skryn'ko, S. (2007) Otsinka mayna ta maynovykh prav [Appraisal of property and property rights], TOV "UKTS “Ekspert-L", Kyiv, Ukraine.

6. Petrov, M. I. (2002) "Economic security of the enterprise: essence, interpretation, point of view", Menedzher, vol. 1, pp. $67-71$.

7. Petryayeva, Z.F. Ivashchenko, G. A. and Petryayev, O.O. (2016) "Verification of graduation levels of financial and economic security of enterprises”, Aktual'ni problemy ekonomiky, vol. 5, pp. $402-411$. 